\title{
Visual Communication
}

http://vcj.sagepub.com/

\section{Book Review: Multimodality: A Social Semiotic Approach to Communication}

Eva Insulander

Visual Communication 2011 10: 593

DOI: $10.1177 / 1470357211415796$

The online version of this article can be found at:

http://vcj.sagepub.com/content/10/4/593.citation

\author{
Published by: \\ (A) SAGE \\ http://www.sagepublications.com
}

Additional services and information for Visual Communication can be found at:

Email Alerts: http://vcj.sagepub.com/cgi/alerts

Subscriptions: http://vcj.sagepub.com/subscriptions

Reprints: http://www.sagepub.com/journalsReprints.nav

Permissions: http://www.sagepub.com/journalsPermissions.nav

>> Version of Record - Oct 14, 2011

What is This? 


\section{Book review}

GUNTHER KRESS, Multimodality: A Social Semiotic Approach to Communication. London: Routledge, 2010. ISBN 978-0415320603

Multimodality is now an established term and field of inquiry and, since its emergence, the term has been used in combination with a variety of theoretical approaches and disciplines. Gunther Kress, one of the pioneers and contributors of this field, sets out his perspective and theoretical assumptions in his latest book entitled Multimodality: A Social Semiotic Approach to Contemporary Communication. The social semiotic approach to multimodality involves a focus on the uses of texts and modal resources in communication. According to Kress, it entails a move away from the more strict interpretations of grammar and emphasizes the creative aspects of communication and the choices and interest of the sign-maker. Even though Kress outlines a theory of communication, this book is completely accessible to scholars in other fields and it provides useful research tools that can be applied across different areas of research. Articulated in this book, for instance, is the connection with pedagogy and education, as Kress engages in questions of learning in different multimodal contexts.

In his book, Kress presents a wide range of terms that are central to a social semiotic approach to multimodality. Asking how meanings are made, he analyses such topics as parking regulations and classroom design, as well as drawings by museum visitors and children, demonstrating how modes and media work together in complex ways. Kress also discusses these examples of contemporary communication from an historical view, showing that signmakers always select and arrange resources in relation to their situated interests and needs. For instance, he discusses excerpts from school textbooks from different periods to show how new technology and the visual have changed meaning-making in a globalized world. Kress's research shows that, while image and writing are used in 'old' (1935) and 'new' textbooks (2002), they serve different functions. In the old one, writing carried all the information that was considered essential to the curriculum, while image was used to illustrate the units and scientific principles already presented in the written text. In the new textbook, on the other hand, image and text have a complementary 
status. Both modes offer specific affordances, and the curriculum may be represented in writing or image, depending on what is considered most apt. By discussing these changes in terms of 'gains' and 'losses', these examples serve as a reminder of the close relation between social, cultural and semiotic change.

One fundamental idea that is outlined throughout this book is how communication is shaped by and shapes the changes in society. Kress points out that the shift towards a post-modern society with less stability and less continuity has affected the conditions of communication - and of learning - in many different ways, both in relation to authority and to the material resources used. In neo-liberal economies, notions of life-long learning and assessment are central ways to obtain 'efficiency' and 'employability'. In this context, it is important to discuss how Gunther Kress's work can be seen as an ethical response to current political situations. Throughout the book, Kress shows how the rearrangement of power has had an effect on communicational environments. For instance, his naming of (young) people as 'designers' or 'authors' highlights that they use media for their own purposes. He argues that both 'rhetoric' and 'agency' need to be taken into account if we are to widen our understanding of the premises of communication in today's society. Without reducing the importance of power relations, he stresses a view of the individual as agentively making meaning, and at the same time being part of a complex and pluralistic society. The ethical aspects of communication are suggested by his selection of examples. Significant in his approach is his interest in seemingly trivial and mundane instances of communication, such as children's drawings. This is a reminder that different aspects of learning and meaning-making can be made visible if we attend to all participants in communication.

Against this background, Kress sketches his theory of communication, addressing questions such as 'What is a mode?' and 'What is design?' 'Old' terms such as 'design', 'resource' and 'interest' are given new meaning to present a different - social semiotic - look at the world. For Kress, design is about how individuals make meaning in a changing world with the semiotic resources that are at hand, according to their interest. The different themes of the book show the variety of what can be done with this approach and they show what might have been left out in other approaches to multimodality. Kress's approach enables the reader to analyse a range of materials and situations in detail without being presented with a merely descriptive account of texts.

The strength of Kress's approach is that it connects the social context with the semiotic work of the designer. Kress's insistence on understanding the choices of form that people make as meaningful - whether they are linguistic forms, graphic forms or related to the body - is what makes his book so engaging. Here, Kress draws on Halliday's notion of choice, but develops it further by applying it to different modes. In his previous work, he has demonstrated that the body is a central resource in making meaning. However, the 
emphasis in this book is on the producers' textual design and on 'inscription' rather than on ongoing activities associated with meaning-making and learning. A discussion of face-to-face interaction, conversation or participation as signs of learning would perhaps have complemented the theoretical claims of this book.

The last chapter consists of a specific case study of how social and technological change can be understood from a social semiotic approach. It was co-written with Elisabetta Adami and illustrates how one central metaphor in today's society, mobility, influences how people make meaning and shape their identity. The analysis of smartphones involves interesting interpretations of the affordances of its design and of the skills that these affordances may support. One conclusion is that the technology affords immediacy, 'multitasking' and selection from among already existing options, over aspects like personal accuracy, interpretation, or 'production from scratch'. In this chapter, Kress moves away from a theoretically oriented and closely reasoned way of writing to an analysis that stands out as more descriptive and specific. The otherwise coherent and thematically ordered book therefore becomes a bit loose at the end.

That said, the book is an important statement of what is distinct about multimodal social semiotics. Written in readable and engaging prose, it offers a rich and creative set of tools for anyone interested in describing, analysing or interpreting contemporary communication. It makes a strong case for multimodality as a central feature of communication by demonstrating how different modes work together in sign-making. From a social semiotic perspective, sign-makers are seen as competent in their use of different resources in order to represent how they understand the world. The emphasis on mode and on multimodal configuration, rather than on a limited view of text, is probably one of the reasons why Gunther Kress's book may already be considered a classic work and an important contribution to the field of social semiotics.

EVA INSULANDER

Stockholm University, Sweden

[email: eva.insulander@edu.su.se; eva.insulander@edu.su.se] 